\title{
The current outlook of human papillomavirus and its association with digestive tract cancer
}

\author{
Perspectiva actual del virus del papiloma humano y su asociación con el cáncer \\ del tracto digestivo
}

\section{O panorama atual do papilomavírus humano e sua associação com o câncer do trato digestivo}

\author{
Isabel Cristina Almonacid Urrego ${ }^{a *}$ | Carmen Cecilia Almonacid Urrego ${ }^{b}$ | Sonia Marcela Rosas \\ Arango ${ }^{~} \mid$ Edith del Carmen Hernández Rojas ${ }^{d} \mid$ Johanna Lizeth González Devia ${ }^{e}$ \\ a https://orcid.org/0000-0002-02 I8-9367 Policía Nacional de Colombia, Bogotá, Colombia \\ ${ }^{b}$ https://orcid.org/0000-0002-4793-5 I83 Universidad Colegio Mayor de Cundinamarca, Bogotá, Colombia \\ chttps://orcid.org/0000-0002-9847-5447 Universidad Colegio Mayor de Cundinamarca, Bogotá, Colombia \\ ${ }^{d}$ https://orcid.org/0000-0002-2874-068X Universidad Colegio Mayor de Cundinamarca, Bogotá, Colombia \\ e https://orcid.org/0000-0003-4I62-6678 Universidad Colegio Mayor de Cundinamarca, Bogotá, Colombia
}

- Fecha de recepción: 2020-07-02

- Fecha concepto de evaluación: 2020-08-26

- Fecha de aprobación: 2020-10-26 https://doi.org/I0.22335/rlct.v|3il.I292

\begin{abstract}
Para citar este artículo / To reference this article / Para citar este artigo: Almonacid Urrego, I. C., Almonacid Urrego, C. C.., Rosas Arango, S. M., Hernández Rojas, E. C., \& González Devia, J. L. (202I). The current outlook of human papillomavirus and its association with digestive tract cancer. Revista Logos Ciencia \& Tecnología, 13(I), I29-I43. https://doi. org//0.22335/rlct.v| 3il.I292
\end{abstract}

\begin{abstract}
Digestive tract cancers are frequent worldwide, despite efforts to control known predisposing factors, they keep increasing, this fact suggests that human papillomavirus (HPV) may play an important oncogenic role in these pathologies. In order to argue the incidence that HPV has in the genesis of gastrointestinal tract tumors and to determine if it is a possible causal agent, the scientific literature published to date on the subject was reviewed, and was found that $4.5 \%$ of all diagnosed cancers correspond to HPV; $12 \%$ are extra cervical, $20 \%$ esophagus, $31.9 \%$ colon adenomas, $43 \%$ colorectal adenocarcinoma, and $35 \%$ head and neck neoplasms (HNSCC). The types of HPV reported in the digestive tract are 6, 9, II, $13,16.18,20,24,25,30,33,51,54,57, \mathrm{DL} 416, \mathrm{DL} 428$ and DL 436. Although, the studies show the HPV impact in the oncogenesis and its role as a prognostic marker in some of them, they do not have hard evidence that reveals this relationship, therefore demonstrating its integration would allow clarifying it.
\end{abstract}

Keywords: human papillomavirus, gastrointestinal cancers, oncogenesis, viral integration 
Isabel Cristina Almonacid Urrego, Carmen Cecilia Almonacid Urrego, Sonia Marcela Rosas Arango, Edith del Carmen Hernández Rojas, Johanna Lizeth González Devia, Revista Logos Ciencia \& Tecnología, I3(I):I29-I43

\section{RESUMEN}

Los cánceres del tracto digestivo son frecuentes en todo el mundo, a pesar de los esfuerzos por controlar los factores de predisposición conocidos, siguen aumentando, este hecho sugiere que el virus del papiloma humano (VPH) puede desempeñar un papel oncogénico importante en estas patologías. Con el fin de argumentar la incidencia que tiene elVPH en la génesis de los tumores del tracto gastrointestinal y determinar si es un posible agente causal, se revisó la literatura científica publicada hasta la fecha sobre el tema, y se encontró que el $4.5 \%$ de todos los cánceres diagnosticados corresponden a VPH; $12 \%$ a extracervical, $20 \%$ a esófago, $31.9 \%$ a adenomas de colon, $43 \%$ a adenocarcinoma colorrectal y $35 \%$ a neoplasias de cabeza y cuello (HNSCC). Los tipos de VPH reportados en el tracto digestivo son $6,9,11,13,16.18,20,24,25,30,33,51,54,57$, DL 4I6, DL 428 y DL 436. Si bien los estudios muestran el impacto del VPH en la oncogénesis y su rol como marcador pronóstico en algunos de ellos, no tienen evidencia contundente que revele esta relación, por lo tanto, demostrar su integración permitiría esclarecerla.

Palabras clave: virus del papiloma humano, cánceres gastrointestinales, oncogénesis, integración viral

\section{RESUMO}

O câncer do trato digestivo é frequente no mundo todo; apesar dos esforços para controlar os fatores predisponentes conhecidos, os casos continuam aumentando, fato que sugere que o papilomavírus humano (HPV) pode desempenhar um importante papel oncogênico nessas patologias. Para discutir a incidência do HPV na gênese dos tumores do trato gastrointestinal e para determinar se é um possível agente causal, foi revisada a literatura científica publicada até $o$ momento sobre $o$ assunto e verificou-se que $4.5 \%$ de todos os cânceres diagnosticados correspondem a HPV; I2\% são extra cervicais, $20 \%$ de esôfago, $31.9 \%$ são adenomas de cólon, $43 \%$ adenocarcinoma colorretal e $35 \%$ neoplasmas de cabeça e pescoço (CECP). Os tipos de HPV encontrados no trato digestivo são 6, 9, 11 , 13, I6, I8, 20, 24, 25, 30, 33, 5I, 54, 57, DL 416, DL 428 e DL 436. Embora os estudos mostrem o impacto do HPV na oncogênese e seu papel como marcador prognóstico em alguns deles, não há evidências concretas que revelem essa relação; portanto, demonstrar sua integração permitiria esclarecê-la.

Palavras-chave: papilomavírus humano, câncer gastrointestinal, oncogênese, integração viral

Digestive Tract Cancer is one of the most common globally, disproportionally affecting the male gender (Stokłosa et al., 2020). In 2020, it has been estimated that 387,000 new cases of cancer in the digestive system, the oral cavity and the pharynx will have been diagnosed, along with 179,000 related deaths in the United States (Siegel et al., 2020). Despite the repeated efforts to control the predisposing factors, such as smoke, alcohol and diet; several countries have reported an increase in the frequency of such pathology (Aguilar Huergo et al., 2017).

Cancers located in the sinonasal tract, oral cavity, nasopharynx, oropharynx, hypopharynx and larynx, are included in the group of squamous cell cancer of the head and neck (HNSCC), which is the sixth most common cancer worldwide; even though it is rare in the United States, it is very common in southern European countries (Elkashty et al., 2019).

Among the different types of cancer with the highest incidence worldwide, Colorectal Cancer corresponded to $11.8 \%$ of all cancers in 2018 , followed by Esophagueal Cancer (EC) which ranked eighth in the list of cancers with the most incidence internationally (Bray et al., 20I8).

The etiological factors of digestive tract cancer include eating habits, smoking, alcohol, and infectious agents such as Helicobacter pylori, Epstein-Barr virus and Human 
Papillomavirus (HPV). The presence of the last one has been demonstrated in several reviews (Roesch-Dietlen et al., 2018; Tsikis et al., 2016), and its identification in these cancers has generated discussion due to the fact that it is more frequently found in cervical dysplasia (Chan et al., 2019).

Owing to its impact on public health, this article describes the findings related to HPV as a risk factor in developing digestive tract cancers (oral, esophagus, colon, stomach, and anus cancer).

\section{Human papillomavirus characteristics}

Human Papillomavirus (HPV) belongs to Papoviridae family, and therefore, it is included in papillomavirus type. They are small viruses, non-enveloped, with an icosahedral structure and a diameter of about $55 \mathrm{~nm}$, whose genome is comprised of a circular double-stranded DNA consisting of 7000 to 8000 base-pairs. There are several types of this virus family, of which only the Alpha, Beta and Gammapapillomavirus infect humans. More than 200 types of HPV have been described with tropism by stratified squamous epithelium, infecting the skin, oral mucosa and/ or anus-genital tract mucosa. Cutaneous HPV varieties, including types I, 2, 3, 7 and I0 mainly target the hands and feet, and they form typical infection warts. HPV prefer the mucosal tissues and mostly infect the genital mucosa, but they have also been detected in respiratory and digestive mucosa, in the basal epithelial cells of the mouth, throat, respiratory tract or anus-genital epithelium, in any of which HPV could give rise to a carcinogenic process. There are about 40 different types of HPV that are transmitted sexually, and they are grouped into oncogenic low-risk HPV (LR) and high-risk HPV (HR). LR HPV's include the most frequent types $6,1 \mathrm{I}, 42,43$ and 44 , of which, the most important types are 6 and II that cause genital warts in both men and women. HR HPV's are types 16,18 , $3 \mathrm{I}, 33,34,35,39,45,5 \mathrm{I}, 52,56,58,59,66,68$ and 70 (Gheit, 2019; Jing et al., 20I8; Martínez-Ramírez et al., 2018).

Structurally, HPV is approximately 55 to $60 \mathrm{~nm}$ and it is made up of three regions. The first region, called "Early Region", encodes non-structural proteins and corresponds to $45 \%$ of viral genome; this region comprises the EI, E2, E4, E5, E6 and E7 genes, which are implied in the cellular regulation and transformation. The second region, called "Late Region", corresponds to $40 \%$ of genome and encodes the structural proteins of the viral capsid; the genes involved in this region are $\mathrm{LI}$ and L2. Finally, the third region known as "LCR Region" or "Long Control Region" has transcriptional regulatory function for viral genes E6 and E7 (Gheit, 2019) (Figure I).

Figure I. Genomic Organization of Human Papillomavirus (HPV) 16.

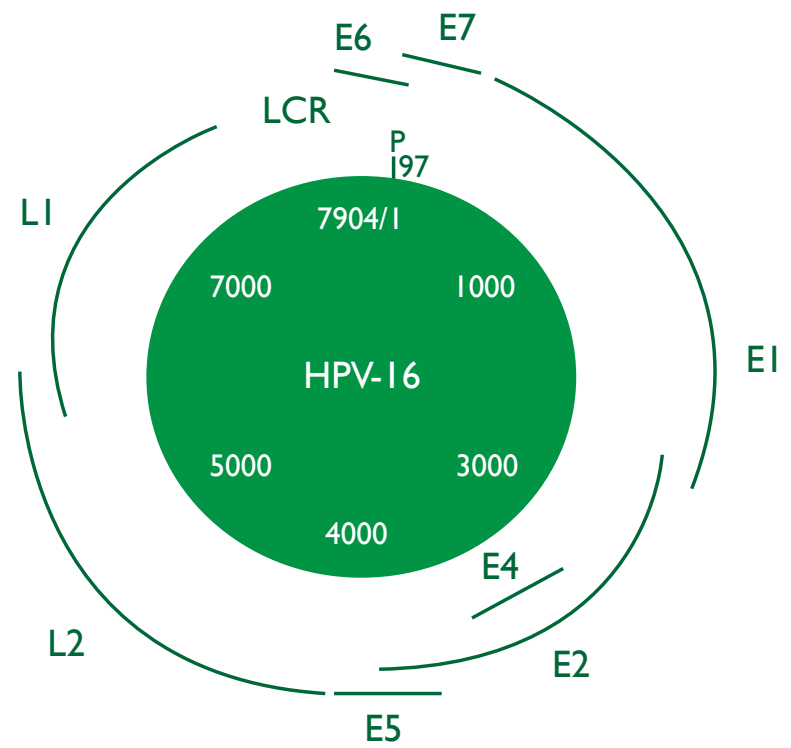

The HPV genotypic variability in the general population with pre-cancerous lesions and cancer varies worldwide and even their behaviour is versatile within a population or region. Various studies have shown that the presence of HPV is a predisposing factor for the development of cervical cancer (CC) (Chan et al., 2019; Salina et al., 2019) along with cancers of the digestive tract (Berman \& Schiller, 2017; Morgan et al., 2017). On the other hand, worldwide, cervical cancer is the fourth most frequent cancer in women, with an incidence rate by age of 15.2 per 100000 .Around half a million new cases are detected each year and slightly more than half lead to death, being the third leading cause of cancer among women, with a rate of age-adjusted mortality of 6.6 per 100 000.According to Globocan 2018 Statistics (Bray et al., 2018), CC is the third most common cancer in Colombia and remains the leading cause of death among women, establishing its reduction as one of the goals of global development in the Millennium Development Goals for 2015.

Each year, esophagueal and gastric cancers (GC) cause more than 900000 deaths worldwide. It has been suggested that HPV, especially type 16, may have an important role in EC. Over the past 20 years, several studies have used a variety of techniques, including DNA detection of HPV in tumour tissues of the esophagus, in order to find the association of the virus exposure and the risk of developing squamous esophageal carcinoma (ESCC). 
Isabel Cristina Almonacid Urrego, Carmen Cecilia Almonacid Urrego, Sonia Marcela Rosas Arango, Edith del Carmen Hernández Rojas, Johanna Lizeth González Devia, Revista Logos Ciencia \& Tecnología, I3(I): I 29-I43

Investigations in Colombia and Mexico have exposed the relationship between HPV and cancers and pathologies close to the aerodigestive system, presenting an incidence in the oropharynx of $35.6 \%, 23.5 \%$ in the oral cavity and 24.0\% larynx (Serena-Gómez et al., 20I I).A study, carried out in Medellin - Colombia, described the presence of HPV 16 and 18 in patients with HNSCC (Quintero et al., 2013). Another study carried out in Cali - Colombia describes HPV detection in DNA samples obtained from the oral mucosa of 76 healthy women. The percentage of detection was $6.6 \%$. The types detected were HPV II, HPV 43 and HPV 72 (Zambrano-Ríos et al., 2019).

Nonetheless, in Colombia, the HPV situation is still unclear in terms of other types of digestive tract cancers, due to the limited number of studies carried out. On the contrary, in the United States and other places around the world a considerable amount of research has been carried out regarding the association of HPV with oral, esophagus and pharynx cancers (Taberna et al., 20l7).

\section{Infection pathogenesis}

Some studies have tried to explain the pathophysiology and the infection model of HR HPV in the cervical epithelium. During sexual intercourse, a micro-trauma is produced allowing the entry of virions to the basal layer of the cervical epithelium, owing to the fact that HPV only infects mucosal tissue cells which multiply. This happens through the union of cell receptors with the virus, mainly heparin sulfate (HS) with HPV 16 and $\alpha 6$ - integrin to HPV 6 (Athanasiou et al., 2020).

The virus incubation time is not completely established; however, it appears to be somewhere between 6 weeks and 2 years. HPV infection is transient in $90 \%$ of infected people, clearing up after 2 years. The virus is removed naturally by the immune system without any kind of treatment, and only $10 \%$ of cases persists beyond this period. Notwithstanding, reinfections can appear, mostly with different strains farther from phylogenetic tree, owing to the fact that the different strains are very similar or close in their phylogeny and this can produce immunologically cross-reactions (Chan et al., 2019). This is of particular interest when it comes to application studies and vaccine coverage (Min et al., 2018).

When a LR HPV infects a cell and produces new viral particles (productive infection), DNA viral episomal is conserved within the nucleus, meaning that the viral genome is not integrated into the cell genome, so the risk of malignant transformation is low, but when the infection lasts for over 2 years and does not clear up (persistent infection) and it has an oncogenic strain (high-risk), the risk of developing cancer is higher. (Chan et al., 2019). These two conditions are called the "process of oncogenic initiation", but this process alone is not enough, inasmuch as it is indispensable the action of several promoting agents accepted nowadays as, immunocompromised relative, individual susceptibility according to polymorphism MCH (Major Histocompatibility Complex), deficiencies of vitamins A, C, E or Zinc, or co-infections with Chlamydia and Herpes Virus, and smoking (Gheit, 2019;Tóth, 20I8).

The integration of viral DNA into the cellular DNA takes place before malignant cells transform into HR HPV. The integration of viral DNA causes changes in both the genomes which imply cellular genomic instability and overproduction of viral oncogenesis (E6 and E7) that operate on the proteins $p 53$ and $\mathrm{Rb}$, which are essential genes in tumour suppression (Tóth, 2018).

It is noteworthy that the difference in risk for progression to carcinoma is in the persistent infection and therefore in the integration of viral DNA into the host cell. Experimental investigations suggest that integration into the genome is the result of the instability and commitment of chromosomal integrity in basal cells, and is supported by the manifestation of E6 and E7 oncoproteins. (Vonsky et al., 2019;Tóth, 2018) (Figure 2).

When cells are infected with HPV, the virus replication begins through transcription factors of the host cell and the viral El protein is in charge of starting the viral DNA replication and transcription. The E7 protein binds to the retinoblastoma protein (RB), freeing the transcription factor E2F_I, and it causes the activation of genes that increase cell proliferation. The Oncoprotein E6 induces p53 ubiquitination and degradation, and this generates the apoptosis mediated by $p 53$. Oncoprotein E2 regulates the transcription of oncoproteins E6 and E7. E5 increases the cellular kinases action that helps proliferation and decreases cellular differentiation. E4 promotes the assembly of proteins from the viral capsid LI for the virion packaging of HPV and the subsequent release. Adapted from "Diagnostic of VPH infection in male". (Modified by Silva et al., 2013).

The oncoprotein E6 provides cellular immortalization potential from two mechanisms that include actions on 
Figure 2. HPV Pathogeny Mechanism.

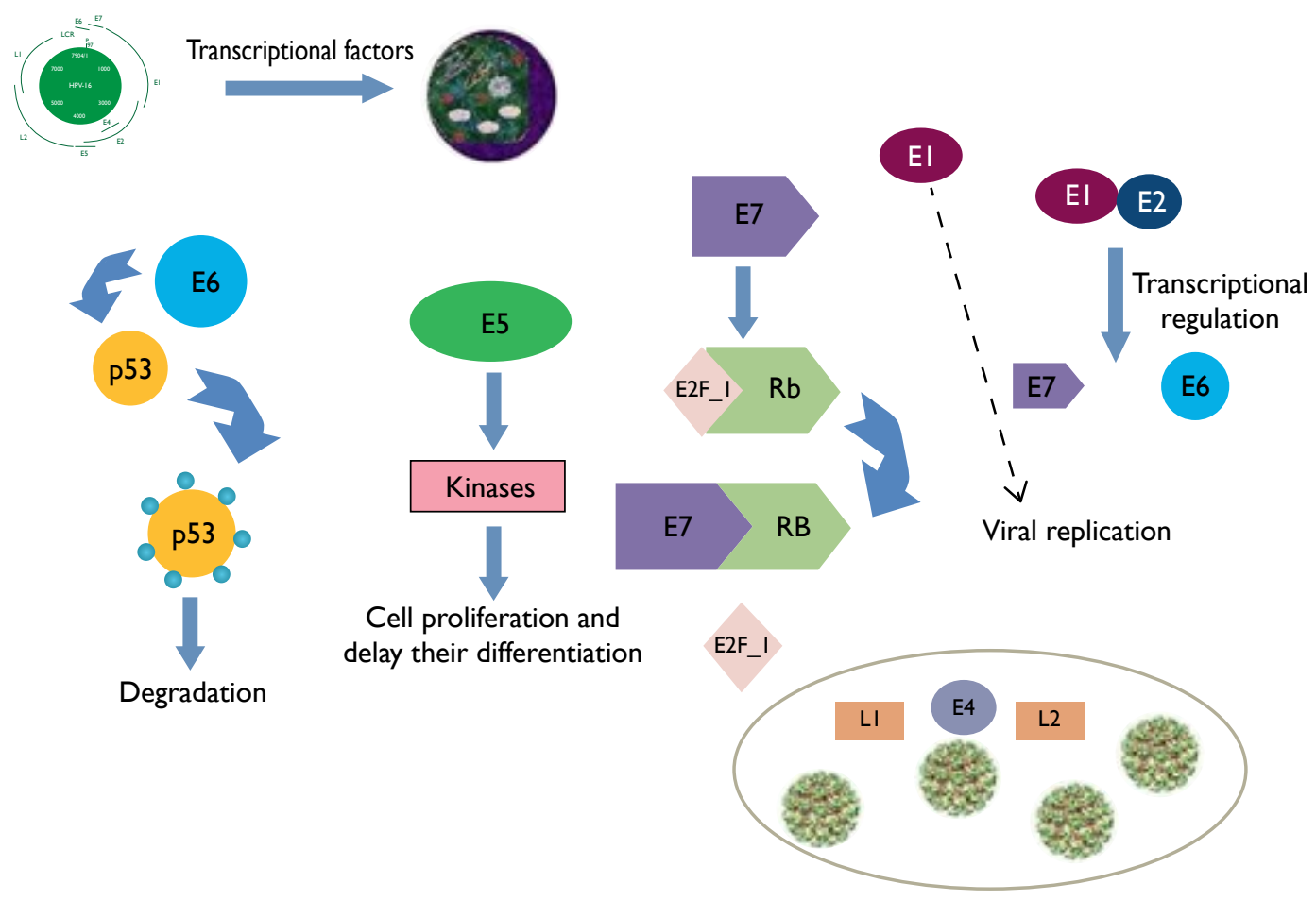

or independent of the $\mathrm{p} 53$ protein. In terms of its effect on $\mathrm{p} 53$, E6 employs the enzymatic complex needed to proteolysis by ubiquitination, which compromises the signposting in the cellular cycle control (cycle stop); this helps with the integration of viral DNA inside host cells. The principle of this mechanism is the induction of its degradation through the conduit of proteasome-ubiquitin. (Tóth, 2018; Vonsky et al., 2019).

In the mechanism, that contains independent actions from the $\mathrm{p} 53$ protein, $\mathrm{E} 6$ has the ability to interact with kinases; it increases the rate of mitosis activity and degrades protein complexes placed in the cytoskeleton-membrane interface which regulates the growth, proliferation, polarity and cell adhesion. Moreover, it presents the capability to induce the telomerase activity, which generates active persistence that contributes to the epithelial cells immortalization when it conserves the telomere size and raises the number of cell divisions. Recently, they have been associated to carcinogenesis processes induced by $\mathrm{E} 6$ and other oncogenes such as the RAS family (K-RAS, H-RAS, $\mathrm{N}-\mathrm{RAS}$ ), Notch- I, and c-Myc, all of which are related to the transduction of cellular signals that promote the manifestation of the different cancer stages (Vonsky et al., 2019).

Oncoprotein E7 encodes a protein that has three conserved regions which denote in an analogous form the EIA protein of adenovirus such as CRI, CR2 and CR3, which are essential for $\mathrm{pRb}$ binding and degradation. The experimental studies suggest that the union of E7 to $p R b$ generates the synthesis in the $S$ phase of cyclins $A$ and $E$ cellular cycle, helping its progression, while at the same time, attenuating the dependent kinases inhibitors activity (CDKI: p2I y p27) (Gheit, 20I9). Moreover, it presents the ability to cause genomic instability by originating an imbalance in chromosomic segregation as a result of the unusual amplification of centrosomes or centromeres dysfunction. It has even been established that protein E7 of HPV type 16 blocks IFN- $\alpha$ activity and the promotor of IFN- $\beta$, which have an antitumor and antiviral effect.

Moreover, the role of Tool Like Receptors (TLRs) and their relation with chronic inflammation and direct damage to tumour cells as well as chemoresistance has recently been reviewed.Also, in 2017, an increased expression of TLR 5 and TLR 7 in HPV cancer in the oral cavity that leads to a prognostic value was reported (Jouhi et al., 2017).

Recent research on HPV infection as a risk factor in the pathogenesis of esophageal, larynx, and oral cavity cancer has focused on the viral DNA detection and the determination of its cellular genome integration stage. This research opposes the cervical cancer studies in which great advances have been made globally (Husain \& Neyaz, 2017; Pan et al., 2018;Tóth, 20I8). 
Isabel Cristina Almonacid Urrego, Carmen Cecilia Almonacid Urrego, Sonia Marcela Rosas Arango, Edith del Carmen Hernández Rojas, Johanna Lizeth González Devia, Revista Logos Ciencia \& Tecnología, I3(I): I 29-I43

Nowadays, vaccines against infection by the main HPV genotypes have been developed. The bivalent vaccine (Cervarix) includes genotypes 16 and 18 , and the tetravalent vaccine (Gardasil) includes genotypes 6, II, 16 and 18. These vaccines have demonstrated a high protection against certain strains of HPV; however, as mentioned above, they only provide protection against 4 out of the 40 existing genotypes (Athanasiou et al., 2020; Min et al., 2018).

\section{HPV and its association with cancer}

The historical background of the epoch and the way in which the first HPV strain was described are not precise; nevertheless, HPV was defined, for the first time, as a disease by Dr. Richard Shope from Rockefeller University in the 1930s. Shope experimented with samples of rabbits warts which he injected into healthy rabbits. He observed that a papilloma virus strain from infected rabbits often causes horn-shaped warts. Although Shope did not identify HPV, he was right in proclaiming that the warts were produced by a virus (Shope, 1937).

In the 50's, many scientists, through an electron microscope described HPV as a virus that was found inside skin warts. (Riviere, \& Bernhard, 1960) Then, in the 70's and 80's, the German scientist and virologist Harald zur Hausen and his colleagues described the HPV DNA inside cervical cancer tumours (lkenberg et al., 1983; Zur Hausen, 1983).

The great importance in the health field of HPV was revealed with the knowledge about its oncogenic potential and its association with human tumours, especially with CC that represents the second most common cancer in women worldwide. Its global incidence is 530,000 cases per year, $80 \%$ of which correspond to developing countries with an approximate mortality rate of $50 \%$ (Bray et al, 20I8).

Etiologically, HPV's are associated with almost 100\% of CC cases. They are also linked with the development of extra cervical neoplasias such as vulvar and vaginal cancers $(40 \%)$, penis cancer $(40 \%)$, anus cancer $(90 \%)$, head and neck cancer, especially oropharyngeal (nasal cavity, tonsils, tongue and mouth), where they have a prevalence of $35 \%$. Notwithstanding, the incidence of all extra cervical cancers associated with HPV is only $12 \%$ of the total number of cancers related to this virus; this finding focuses $C C$ as the main clinical and economical reason for prevention (Otter et al., 2019).
It is estimated that worldwide $4.5 \%$ of diagnosed cancers correspond to HPV, of these cases $8.6 \%$ are in women and $0.8 \%$ in men. The types recovered correspond to HPVI 6/I8 and HPV 6/I I/I6/18/3I/33/45/52/58 (de Martel et al., 2017).

\section{HPV and its association with} digestive tract cancers

Literature describes an average incidence of more than $20 \%$ of HPV infection in EC, $31.9 \%$ in colon adenomas and $43 \%$ in colorectal adenocarcinomas. The types reported in digestive tract cancers are $6,9,11,13,16,18,20,24,25$, $30,33,5 \mathrm{I}$ to $54,57, \mathrm{DL} 23 \mathrm{I}, \mathrm{DL} 4 \mathrm{I}$, DL428 and DL 436 (Pérez et al., 2003).

Presently, EC is the third most frequent of the gastrointestinal neoplasias malignancies and the seventh in the western world. Its incidence has increased in recent years, mainly in those which are located in the gastroesophageal union, due to its relation with intestinal metaplasia. Malignancies of the upper gastrointestinal tract that originate in the esophagus, gastrointestinal union, and stomach represent a health problem in the whole world. Worldwide each year, 400000 EC cases are diagnosed, and it currently ranks seventh in frequency (3.2\%). Likewise, and due to its extremely aggressive nature and reduced survival, it stands as the sixth leading cause of cancer mortality in the world (Abnet et al., 2018).

While EC is clearly associated with smoking and alcoholism (Abnet et al., 2018; Guo et al., 2016), its association with HPV is still controversial. There have been studies that reveals a possible role of HPV in the early stages of carcinogenesis and they show an increase in the risk for EC after HPV infection (Li et al., 2018; Saxena et al., 2016; Tasneem et al., 2019) while others question these data (Agalliu et al., 20I8; Halec et al., 2016). The histological similarities between the esophagus and the cervix and the identification of a transformation zone in the lower esophagus, similar to that which is found in the cervix, has led some scientists to suggest that similar pathological events could happen in these two organs and they have suggested that the human papillomavirus (HPV) infection could be a probable explanation (Georgantis et al., 20I5).

The first document about the association of HPV and lesions of the uterine cervix was made in 1982 by 
Dr. Syrjanen, who demonstrated the human papillomavirus antigen in the condylomatous lesions of the uterine cervix by using the immunoperoxidase technique. (Syrjänen \& Pyrhönen, 1982). In 1994 a study was carried out in the United States where 23 ESCC were molecularly analysed, demonstrating the presence of viral DNA in one of them (Carr et al., 1994). Later in 1997, researchers from the European Union examined 63 tissues from patients with ESCC by PCR and they did not find the presence of the virus in any of the samples (Kok et al., 1997). However, in 2005, India reported a case of a I5 years child diagnosed with ESCC, and in this case HPV 16 was isolated (Tampi et al., 2005). Investigations carried out in 2009 in Spain and Italy describe the presence of HPV in $54 \%$ of cases of ESCC and $27.8 \%$ of cases of GC, including types 6 and 16 (Junquera et al., 2009; Tornesello et al., 2009). A comparative study between China and the EU undertaken in 2010, which included 34 tumoral samples of esophageal adenocarcinomas and $40 \mathrm{I}$ samples of ESCC, concluded that the HPV infection is very frequent in EC, especially in the region and ethnic group analysed (Wang et al., 2010). The following year, in the United States, lyer et al., described the presence of HPV in $31 \%$ of population with GC (lyer et al., 20II). Later, in 2012, an investigation carried out in Iran analysed esophageal tissues with ESCC and found HPV in $27.68 \%$ of the study population; the most common genotypes were 45 and II followed by 6, 52 and 39 (Yahyapour et al., 2013). In the same year, as demonstrated in the review published by Durruthy and Colleagues, the prognostic value of HPV in patients with EC, evaluated by many authors, shows that HPV positive patients have the worst prognostic (Durruthy Wilson et al., 20I2).In 2013 two studies identified HPV in this cancer, one made in Africa in which they identified HPV 18 in $9 \%$ of patients with ESCC, and another study made in China, in which they determined that HPV infection may be one of the many factors that contribute to developing EC (type 16 is the most frequent), (Schafer et al., 2013; Vieira et al., 2013), along with a research made in Portugal where they reported the presence of HPV 11 in a patient with ESCC (Li et al., 20I4). In recent years, various researchers have found an association between HPV and EC in patients from Pakistan (Tasneem et al., 2019), China (Dong et al., 20I5; Li et al., 2018) and India (Saxena et al., 2016).

The association between HPV and oral cancer has been described in Italy since 2002, where a prevalence of 61.5\% were found in oral lesions (Giovannelli et al., 2002), while another study made in the same country in $201 \mathrm{I}$ found a lower prevalence (14.3\%), that related to women who had a HPV infection in the cervix (Termine et al., 20 I I). A study conducted in Finland concluded that the natural history of HPV in oral mucosa is similar to genital HPV infection (Rintala et al., 2006). In 20I2, a study evaluated 177 newborn babies from Milan and it identified HPV in $14.1 \%$ of the population with 8 different genotypes, five $\operatorname{HR}(16,18,31,33$ and 58) and two LR (8I and 84), (Martinelli et al., 20I2). In 20I4, the Universitätsklinikum Köln of Germany found that although $45.7 \%$ of its population was negative for HPV in the genital tract, $5.1 \%$ was positive for HPV. From this group, 57.1\% had LR HPV in the oral cavity and oropharynx (Meyer et al., 20I4). Equally, in 2013, a study conducted in Japan on 93 patients with a diagnosis of squamous oral cell carcinomas proved that $10.7 \%$ of the population was positive to several types of $L R$ and HR HPV, and HR types 33, 35, and 45 were predominant (Ono et al., 20I4). In 20I7, in a study that included 13089 people between the ages of 20 to 69 who participated in a National Health and Nutrition Examination Survey (NHANES) between 2009 and 2014 had their DNA tested for oral HPV. The oncogenic oral HPV DNA was detected in $3.5 \%$ of all adults between 20 and 69 years of age; however, the lifetime risk of oropharyngeal cancer was low (37 per I0000) (D'Souza et al., 20I7).

Finally, in 2018, a prospective analysis conducted on seventy-six patients from the Central Asia region with verified oral or oropharyngeal cancer, showed fourteen cases positives for HPV by PCR and I5 cases of pl 6 IHC from the 35 oropharyngeal tumours, indicating a rate of $25.7 \%$, and from the $4 \mathrm{I}$ oral tumours, five were HPV DNA and six p $16 \mathrm{IHC}$ positive, indicating a rate of $12.2 \%$. These positivity rates are lower than those found in the western world (Adilbay et al., 20I8).

Few studies address this topic in Latin America. An international cross-sectional study to evaluate the prevalence of viral DNA and other markers of HPV related carcinogenesis in formalin-fixed and paraffin-embedded HNSCC samples, identified at 44 centres in 29 countries in Europe,Africa,Asia and America, showed prevalences of 8.6\% for oral cancer in Central and South America, 7.8\% in Europe, 3.4\% in Africa and I\% in Asia, without distinction of sex (Castellsagué et al., 2016). In Colombia, studies have looked at the relation between HPV and oral cancer.A study of HPV ESCC demonstrated the presence of 
Isabel Cristina Almonacid Urrego, Carmen Cecilia Almonacid Urrego, Sonia Marcela Rosas Arango, Edith del Carmen Hernández Rojas, Johanna Lizeth González Devia, Revista Logos Ciencia \& Tecnología, I3(I): I 29-I43

the virus in $29 \%$ of the samples. The evaluated cases were samples of Chilean and Colombian patients who presented subtypes 16 and 18 (16 in Chilean samples and 18 in Colombian samples), (Dreilich et al., 2006). In a crosssectional retrospective study conducted in four pathology laboratories located in Medellin, Colombia out of 175 patients with HNSCC diagnosed between 1999 and 2008, the overall HPV prevalence was $18.9 \%$. HPV was found in $23.9 \%, 17.5 \%$ and $13.3 \%$ of the oral cavity, larynx and oropharynx cases respectively. Among HPV positive cases, $82 \%$ were HPV 16 and $18 \%$ were HPV 18. No other HPV genotypes were identified (Quintero et al., 20I3). In other multicentric descriptive cross-sectional studies conducted in Bogota and Manizales between 2014 and 2017 in 26 samples with oropharyngeal squamous cell carcinoma (OSCC) confirmed by histopathological findings, found that in patients with ESCC, HPV and HPV- 16 frequencies were $84 \%$ and $61.5 \%$, respectively. In contrast, in patients without OSCC the frequencies were 34.6 and $30.7 \%$. Additionally, a higher frequency of S. anginosus + HPV co-infection and S. anginosus + HPV-16 was observed in patients with ESCC in comparison with individuals without OSCC, suggesting the importance of detecting $\mathrm{HPV} / \mathrm{HPV}-16$ and S. anginosus simultaneously in individuals at risk of developing OSCC (Robayo et al., 2019).

In relation to anal cancer, the first studies carried out in Switzerland and the Netherlands in 1989 and 1992 published the first case in each country of men with HPV 16 (Melkert et al., 1992; Rüdlinger \& Buchmann, 1989). In 201 I, Olga Valari and colleagues studied 235 Greek women with HPV cervical infections, of which 109 showed anal infection with HR types (Valari et al., 20I I). In 20I3, an investigation conducted in Turkey analysed 106 patients with $\mathrm{CC}$ found a prevalence of anal infection in $5 \mathrm{I} .1 \%$ of all the cases of HR HPV (Guler et al., 20I3). Lastly, a 2015 study conducted in Korea reported an extremely rare case of anal Giant Condylomata Acuminatum caused by HPV 6 (Hyun et al., 2015). Hidalgo and others demonstrated in 2018 that women who live with HIV have a higher prevalence and incidence of anal precursor lesions (high-grade squamous intraepithelial lesions) than cervical lesions.

Therefore, the screening for these lesions should perhaps be offered to all women living with this virus (HidalgoTenorio et al., 2018). In 2019, the National Cancer Database (NCDB) registry was used to identify a cohort of non-metastatic anal cancer patients treated with curative intent between 2008 and 20 I4, Kabarriti et al., identifying
5927 patients with tumour HPV status for this analysis, 3523 (59.4\%) had HPV positive disease and 2404 (40.6\%) had HPV negative disease. Propensity matched analysis demonstrated that patients with HPV positive locally advanced (T3-4 or node positive) anal cancer had better overall survival $(\mathrm{HR}=0.8 \mathrm{I}(95 \% \mathrm{Cl}: 0.68-0.96)$, $\mathrm{p}=.018)$. In patients with early stage disease (TI-2 and node negative) there was no difference in overall survival $(H R=1.11$ (95\% Cl: 0.86-I.43), $\mathrm{p}=.43)$. These results demonstrate that HPV is a significant prognostic marker in anal tumours, especially for locally advanced disease (Kabarriti et al., 2019). In the same year, Kobayashi et al. analysed 79 high-grade anal squamous intraepithelial lesions from HIV-infected patients and found that 71 (90\%) tested positive for $\geq$ I type of human papillomavirus. The most common type was 16 (39\%), followed by 33 (15\%). HPV type 18 was observed in $3 \%$ of patients. This shows that high-grade anal squamous intraepithelial lesions in HIV-infected patients contain a wide range of types of HPV, and individual lesions commonly harbour multiple types concomitantly (Kobayashi et al., 2019). Tests for anal HPV are not routinely carried out in anal cancer screening, given the high prevalence in high-risk populations. The majority of anal cancers are squamous cell carcinomas (SCC) and around $90 \%$ are attributed to HPV. Human papillomavirus positivity in anal SCC also seems to have a prognostic value, with better survival in patients with positive tumours (Albuquerque \& Medeiros, 2019).

Likewise, HPV have an important role in GC tumorigenesis. In 2009, investigations carried out in Spain and Italy described the presence of genotypes 6 and 16 in ESCC and gastric adenocarcinoma (GA) in $54 \%$ and $27.8 \%$, respectively (Castillo et al., 20I I). In the same year in the USA, the presence of HPV was discovered in $31 \%$ of the population with GC (lyer et al., 20II). In 20I0, a study carried out in China showed the presence of HPV genotype 16 in ESCC and CG in $47 \%$ and $29 \%$, respectively (Ding et al., 2010), and in 2016 a meta-analysis was made in the same country in 1917 cases and found the presence of the virus in precursor lesions (adenomas and dysplasias), genotype 16 was the most frequently associated, followed by genotype 18; hence, HPV is considered as a possible causal factor (Zeng et al., 2016). In the same year, a paraffin block study was made in Iran on 100 patients diagnosed with GC, and it noticed the presence of HPV genotypes 16,18 and 45 in $3 \%$ of GA and $2 \%$ of the gastroesophageal junction, as a result, its definitive 
association could not be confirmed (Fakhraei et al., 2016). One recent study identified $38 \%$ of positive results for HPV in samples from patients with GC and $41.8 \%$ in cases of gastritis. Similarly, they showed an association between HPV and Helicobacter Pylori in gastritis (Bozdayi et al., 2019). These results could lead to new studies in order to clarify the role of HPV in the carcinogenesis of such tumours.

Although Colombia has carried out joint studies with other countries to determine the relationship of this virus with cancers of the digestive tract, its relationship is not yet clear. There are no published studies that demonstrate the association between HPV and GC. However, preliminary results from our research group demonstrated the presence of HPV in $15 \%$ of patients diagnosed with GC, one of which corresponded to genotype 16, while the remaining $(80 \%)$ to other genotypes. This case corresponded to a woman with expression of the pl 6 protein in the previous biopsy, without a gynaecological history of disease, so it can be deduced that it is a primary infection in the stomach and that HPV could be associated as a causal agent of cell transformation, in turn, becoming a risk factor. It is possible that the virus was transmitted orally in such cases.

\section{Molecular biology techniques for HPV diagnosis}

Until now, there is no reliable serological method to diagnose HPV infection.

The most sensitive techniques are the molecular ones; however, they have high costs that are not applicable in some programs. These techniques are based on specific DNA sequences of the virus in material from the area to study. In general, they all consist of facing the DNA sample with a probe whose sequence is complementary to a DNA sequence that needs to be detected (Rodriguez Trujillo, 2018).

Currently, globally, it is possible to use two molecular assays to diagnose and typify HPV. The Hybrid Capture Test, approved by the FDA (Food and Drug Administration) in 2002 (Silva et al., 20I3), and the Polymerase Chain Reaction (PCR) (Rodriguez Trujillo, 2018).
PCR has been developed using several primers with variable sensitivity, so it must be used in conjunction with another analysis technic which allows virus typing; technics such as hybridization with type-specific probes, Sequence or Restriction analysis. Even though, PCR is a complex and expensive technic compared with others, it is extremely specific and sensitive, due to the fact that it can detect nearly 10 and 100 copies of viral genome per sample. The base of PCR includes applying a process which multiplies the number of copies of a DNA viral segment, if it is present in the sample. This process makes it a sensitive technic which is capable of detecting the existence of very few viral DNA copies. Nevertheless, a weakness of the PCR is its inability to quantify, correctly, the viral DNA present in the sample and the need to use complementary probes for each of the HPV types that need to be identified (Rodriguez Trujillo, 2018).

The Cobas ${ }^{\circledast} 4800$ Test Technology is a solution to this inability given that it is the only test with HPV genotyping concurrent and approved by the FDA in 20II.This test is automatic and includes Cobas $X$ equipment to prepare the sample and Cobas $Z$ (Software included) to perform a PCR in real time that amplifies a fragment of the viral LI gene. This reaction is an improved version of the conventional PCR that permits a process of gene amplification and detection in "real time". The simultaneous monitoring of amplification progress is obtained through a chemical reaction that uses fluorescence for a specific detection, it employs specifically instrumentation designed for the reading. This test is intended to detect any of the $12 \mathrm{HPV}$ High-Risk types, plus HPV 66 and 68. Moreover, it allows for the identification, in an individual form and in the same batch, types 16 and 18 (Mateos-Lindemann et al., 2017).

The Hybrid Capture permits the identification of 13 High-Risk HPV genotypes, that cause more than $95 \%$ of worldwide cancers, and 5 Low-Risk HPV genotypes. In this technic, RNA probes can detect Low-Risk genotypes 6, II, 42, 43, and 44, along with High-Risk genotypes 16 , $18,31,33,35,39,45,51,52,56,58,59,68$. When there is no HPV present, a RNA-DNA hybrid is produced that is captured by a specific antibody against hybrids which is detected through a reaction type ELISA by Chemiluminescence that gives information about the quantity of viral DNA in the sample, which is related to the presence of High-Grade lesions. Hybrid Capture requires two probes, one for Low-Risk viruses and another for High-Risk viruses. Its interpretation involves a 
Isabel Cristina Almonacid Urrego, Carmen Cecilia Almonacid Urrego, Sonia Marcela Rosas Arango, Edith del Carmen Hernández Rojas, Johanna Lizeth González Devia, Revista Logos Ciencia \& Tecnología, I3(I): I 29-I43

progressive increase in viral load estimated by Relative Light Units (RLU), it is parallel to the lesion seriousness. For instance, the presence of levels above $100 \mathrm{RLU}$ are associated to lesions in more than 90. By contrast, a high proportion of cases with lower results than 10 RLU do not show lesions, while rates below 5 RLU indicate a small number of viral copies per cell, which indicates latent viral infection or a spontaneous remission phase. In these cases, new sampling is suggested after an interval of 3 months in order to confirm the manifestation of HPV active infections (Ki et al., 2018).

Another technic used includes microarrays, which is based on the amplification of defined sections of HPV genes and the detection through hybridization reaction with immobilized DNA in a microarray system. An eluted DNA is used as the sample. In the first instance, the HPV viral oncogenes, sections E6 and E7 of the sample, are amplified by PCR with a system of multiple initiators which are marked with a fluorescent indicator. Secondly, the products of this reaction are detected in an oligonucleotide microarray. The PCR fluorescent product hybridization with its correspondent oligonucleotide probe is detected by using a special microarray scanner and the signals of all the spots are analysed using software, and finally, the test results are interpreted (Zhang et al., 2018).

DNA Microarrays are composed of DNA molecules (probes) such as small microscopic spots located in defined positions on a solid surface (e.g. glass). The probes differ from each other by their DNA sequence and by the order of their nucleotides. Finally, if the sample DNA contains fragments that are articulated with microarray probes, they are hybridized (Zhang et al., 20I8).

The specificity is guaranteed by the primers and probes design, in addition to the PCR conditions and hybridization. The amplified sections of different HPV types do not show cross reactivity with any other probes when a double DNA chain is used in a concentration between the lowest detection limit and 2 million DNA copies (Guerrero-Gómez \& Guerrero-Florez, 2016).

The Liquid Microsphere Microarray Assay (LBMA) is a newly developed high-performance platform that covers a wide range of genotypes. LBMA platforms are considered valuable tools for the detection and genotyping of HPV in the general population, which has shown high sensitivity and specificity in the Korean population with cervical cancer (Moon et al., 2019).
The detection of HPV infection through molecular techniques is really significant because of their great sensibility and high negative predictive value, which means that their negativity allows for the exclusion, with an elevated degree of confidence, the existence of a high-grade premalignant lesion. As a result, it is important that they be included in viral detection in studies of patients with cancers associated to HPV as a causal factor.

In conclusion, different studies have shown that HPV is an oncogenic virus, and can be considered a causative agent of different malignant epithelial tumours such as the cervix, rectum, anus, vulva and oropharynx, among others. Recently it has been found present in other tumours such as those of the digestive tract, suggesting its possible role in the pathogenesis of these neoplasms. However, its demonstration as an etiological agent of cancer in the digestive tract through its integration has not yet been reported in the literature, to this is added the difficulty to demonstrate viral infection that involves the use of molecular techniques from paraffin tissue, implying high costs and high levels of expertise, in turn, preventing its routine use. It is important to remember that HPV infection is the most common sexually transmitted disease in the world, and therefore, given that it is an oncogenic virus, it may be present in the activation of the different molecular pathways of cancer, a situation that could explain the increased incidence of malignant neoplasms.

Note: The authors, all members of the "ECZA research group", declare that there are no conflicts of interest in relation whit the this article and it was financed by their own economic resources.

\section{References}

Abnet, C. C., Arnold, M., \& Wei, W. Q. (2018). Epidemiology of esophageal squamous cell carcinoma. Gastroenterology, I 54(2), 360-373. https://doi.org//0.1053/j.gastro.2017.08.023

Adilbay, D., Adilbayev, G., Kidirbayeva, G., Shipilova,V., Sadyk, Z., Koyanbekova, G., Sokolenko, E., \& Klozar, J. (20I8). HPV infection and PI6 expression in oral and oropharyngeal cancer in Kazakhstan. Infectious Agents and Cancer, I3(I), I-4. https://doi.org// 0.1 I86/s /3027-018-0175-8

Agalliu, I., Chen, Z., Wang, T., Hayes, R. B., Freedman, N. D., Gapstur, S. M., \& Burk, R. D. (20/8). Oral alpha, beta, and gamma HPV types and risk of incident esophageal cancer. Cancer Epidemiology and Prevention Biomarkers, 27(10), I | 68-I | 75. https://doi.org/ I0. I I58// 055-9965.EPI- | 8-0287 
Aguilar Huergo, S., Alberti Vargas, F., Alonso Herrero, A., Alvarez-Mon Soto, M., Aparicio Urtasun, J., Artal Cortes, A., ..., Viala Monleón, A. (2017). Manual SEOM de prevención y diagnóstico precoz del cáncer. Sociedad Española de Oncología Médica. https://seom.org/seomcms/images/stories/ recursos/Manual_SEOM_Prevencion_2017.pdf

Albuquerque,A., \& Medeiros, R. (2019). New insights into the role of human papillomavirus in anal cancer and anal wart development. Acta Cytologica, 63(2), I 18-123. https://doi. org/I0.1I59/00049/8I5

Athanasiou, A., Bowden, S., Paraskevaidi, M., Fotopoulou, C., Martin-Hirsch, P., Paraskevaidis, E., \& Kyrgiou, M. (2020). HPV vaccination and cancer prevention. Best Practice \& Research Clinical Obstetrics \& Gynaecology, 65, 109-124. https://doi.org//0.1016/j.bpobgyn.2020.02.009

Berman,T.A., \& Schiller,J.T. (2017). Human papillomavirus in cervical cancer and oropharyngeal cancer: One cause, two diseases. Cancer, I23(12), 2219-2229. https://doi.org//0.1002/ cncr.30588

Bozdayi, G., Dinc, B., Avcikucuk, H., Turhan, N., Altay-Kocak, A., Ozkan, S., ...,Bostanci, B. (2019). Is human papillomavirus and helicobacter pylori related in gastric lesions? Clinical Laboratory, 65(10). https://doi.org//0.7754/Clin. Lab.2019.181244

Bray, F., Ferlay, J., Soerjomataram, I., Siegel, R. L., Torre, L. A., \& Jemal, A. (2018). Global cancer statistics 2018: GLOBOCAN estimates of incidence and mortality worldwide for 36 cancers in 185 countries. CA:A Cancer Journal for Clinicians, 68(6), 394-424. https://doi.org/I 0.3322/caac.21492

Carr, N., Bratthauer, G., Lichy, J., Taubenberger, J., Monihan, J., \& Sobin, L. (1994). Squamous cell papillomas of the esophagus: A study of 23 lesions for human papillomavirus by in situ hybridization and the polymerase chain reaction. Human Pathology, 25(5), 536-540. https://doi. org/I0.1016/0046-8177(94)90128-7

Castellsagué, X., Alemany, L., Quer, M., Halec, G., Quirós, B., Tous, S., ..., ICO International HPV in Head and Neck Cancer Study Group (2016). HPV involvement in head and neck cancers: Comprehensive assessment of biomarkers in 3680 patients. Journal of the National Cancer Institute, 108(6), djv403. https://doi.org// 0.1093/jnci/djv403

Castillo, A., Koriyama, C., Higashi, M., Anwar, M., Bukhari, M. H., Carrascal, E., ..., Akiba, S. (201 I). Human papillomavirus in upper digestive tract tumours from three countries. World Journal of Gastroenterology, I 7(48), 5295-5304. https://doi. org/|0.3748/wjg.v17.i48.5295
Chan, C. K., Aimagambetova, G., Ukybassova, T., Kongrtay, K., \& Azizan, A. (2019). Human papillomavirus infection and cervical cancer: Epidemiology, screening, and vaccinationreview of current perspectives. Journal of Oncology, 3257939. https://doi.org/10.1 155/2019/3257939

D’Souza, G., McNeel, T. S., \& Fakhry, C. (2017). Understanding personal risk of oropharyngeal cancer: Risk-groups for oncogenic oral HPV infection and oropharyngeal cancer. Annals of Oncology, 28(12), 3065-3069. https://doi. org/10.1093/annonc/mdx535

de Martel, C., Plummer, M., Vignat, J., \& Franceschi, S. (2017). Worldwide burden of cancer attributable to HPV by site, country and HPV type. International Journal of Cancer, I4I (4), 664-670. https://doi.org/I0.1002/ijc.307/6

Ding, G. C., Ren, J. L., Chang, F. B., Li, J. L., Yuan, L., Song, X., ..., Wang, L. D. (2010). Human papillomavirus DNA and PI6 (INK4A) expression in concurrent esophageal and gastric cardia cancers. World Journal of Gastroenterology, I6(46), 590 I-5906. https://doi.org/I0.3748/wjg.v16.i46.590 I

Dong, H. C., Cui, X. B., Wang, L. H., Li, M., Shen, Y.Y., Zhu, J. B., ...Li, F. (20I5). Type-specific detection of human papillomaviruses in Kazakh esophageal squamous cell carcinoma by genotyping both $\mathrm{E} 6$ and $\mathrm{LI}$ genes with MALDI-TOF mass spectrometry. International Journal of Clinical and Experimental Pathology, 8(10), I3156-13165.

Dreilich, M., Bergqvist, M., Moberg, M., Brattström, D., Gustavsson, I., Bergström, S.,..., Gyllensten, U. (2006). High-risk human papilloma virus (HPV) and survival in patients with esophageal carcinoma: A pilot study. BMC Cancer, 6, 94. https://doi.org/I0.I 186/147I-2407-6-94

Durruthy Wilson, O., Piña Napal, J. C., \& Santana Álvarez, J. (2012). Cáncer de esófago y virus del papiloma humano. Revista Archivo Médico de Camagüey, I 6(5), 644-650.

Elkashty, O. A., Ashry, R., \& Tran, S. D. (20/9). Head and neck cancer management and cancer stem cells implication. The Saudi Dental Journal, 3 I (4), 395-416. https://doi. org/10.1016/j.sdentj.2019.05.010

Fakhraei, F., Haghshenas, M. R., Hosseini,V., Rafiei,A., Naghshvar, F., \& Alizadeh-Navaei, R. (20I6). Detection of human papillomavirus DNA in gastric carcinoma specimens in a high-risk region of Iran. Biomedical Reports, 5(3), 37I-375. https://doi.org//0.3892/br.2016.728

Georgantis, G., Syrakos, T., Agorastos, T., Miliaras, S., Gagalis, A., Tsoulfas, G.,...,Marakis, G. (2015). Detection of human papillomavirus DNA in esophageal carcinoma in Greece. World Journal of Gastroenterology, 2 I (8), 2352-2357. https:// doi.org/ $0.3748 / \mathrm{wjg.v2l.i8.2352}$ 
Isabel Cristina Almonacid Urrego, Carmen Cecilia Almonacid Urrego, Sonia Marcela Rosas Arango, Edith del Carmen Hernández Rojas,

Johanna Lizeth González Devia, Revista Logos Ciencia \& Tecnología, I3(I):I29-I43

Gheit, T. (2019). Mucosal and cutaneous human papillomavirus infections and cancer biology. Frontiers in Oncology, 9, 355. https://doi.org/10.3389/fonc.2019.00355

Giovannelli, L., Campisi, G., Lama,A., Giambalvo, O., Osborn, J., Margiotta, V., \& Ammatuna, P. (2002). Human papillomavirus DNA in oral mucosal lesions. The Journal of Infectious Diseases, /85(6), 833-836. https://doi.org//0.1086/339/93

Guerrero-Gómez, O. A., \& Guerrero-Florez, M. (2016). MicroRNAs asociados al cáncer de cuello uterino y sus lesiones precursoras: Una revisión sistemática. Universidad y Salud, I8(2), 345-363.

Guler,T., Uygur, D., Uncu, M.,Yayci, E.,Atacag,T., Bas, K., Gunay,..., Yakicier, C. (20I3). Coexisting anal human papilloma virus infection in heterosexual women with cervical HPV infection. Archives of Gynecology and Obstetrics, 288(3), 667-672. https://doi.org/I0.1007/s00404-013-282I-0

Guo,L.,Liu,S.,Zhang,S., Chen, Q.,Zhang,M., Quan, P., \& Sun,X.B. (2016). Human papillomavirus-related esophageal cancer survival: A systematic review and meta-analysis. Medicine, 95(46). https://doi.org/I0.1097/MD.00000000000053I8

Halec, G., Schmitt, M., Egger, S., Abnet, C.C., Babb, C., Dawsey, S.M., ...,Sitas, F. (2016), Mucosal alpha-papillomaviruses are not associated with esophageal squamous cell carcinomas: Lack of mechanistic evidence from South Africa, China and Iran and from a world-wide meta-analysis. International Journal of Cancer, 139, 85-98. https://doi.org//0.1002/ijc.299I I

Hidalgo-Tenorio, C., de Jesus, S. E., Esquivias, J., \& Pasquau, J. (2018). High prevalence and incidence of HPV-related anal cancer precursor lesions in HIV-positive women in the late HAART era. Enfermedades Infecciosas y Microbiología Clínica (English ed.), 36(9), 555-562. https://doi. org/10.1016/j.eimce.2018.07.003

Husain, N., \& Neyaz, A. (2017). Human papillomavirus associated head and neck squamous cell carcinoma: Controversies and new concepts. Journal of Oral Biology and Craniofacial Research, 7(3), 198-205. https://doi.org//0.1016/j. jobcr.2017.08.003

Hyun, J. S., Kim, G. B., Choi, B. S., Kim, M. S., \& Park, S. G. (2015). Giant anal condyloma (giant condyloma acuminatum of anus) after allogeneic bone marrow transplantation associated with human papillomavirus: $A$ case report. Journal of Medical Case Reports, 9(I), I-5. https://doi. org//0.1 186/1752-1947-9-9

Ikenberg, H., Gissmann, L., Gross, G., Grussendorf-Conen, E. I., \& Hausen, H.Z. (1983). Human papillomavirus type-16-related DNA in genital Bowen's disease and in bowenoid papulosis. International Journal of Cancer, 32(5), 563-565. https://doi.org// 0.1002/ijc.2910320507 lyer, A., Rajendran, V., Adamson, C. S. C., Peng, Z., Cooper, K., \& Evans, M. F. (20II). Human papillomavirus is detectable in Barrett's esophagus and esophageal carcinoma but is unlikely to be of any etiologic significance. Journal of Clinical Virology, 50(3), 205-208. https://doi.org//0.1016/j. jcr.2010.11.015

Jing, Y., Wang, T., Chen, Z., Ding, X., Xu, J., Mu, X., .., Chen, H. (2018). Phylogeny and polymorphism in the long control regions E6, E7, and LI of HPV Type 56 in women from southwest China. Molecular Medicine Reports, I 7(5), 7I3I7|4I. https://doi.org//0.3892/mmr.2018.8743

Jouhi, L., Mohamed, H., Mäkitie, A., Remes, S. M., Haglund, C., Atula,T., Hagström, J. (20।7). Toll-like receptor 5 and 7 expression may impact prognosis of HPV-positive oropharyngeal squamous cell carcinoma patients. Cancer Immunology, Immunotherapy: Cll, 66(12), 1619-1629. https://doi. org/ I0.1007/s00262-0I7-2054-3

Junquera, F., Videla, S., Cañadas, M. P., Darwich, L., Calvet, X., Brullet, E., ..., Campo, R. (2009). Alta prevalencia del virus del papiloma humano en una población española con neoplasia de esófago. Gastroenterología y Hepatología, 32(3), 227-228. https://doi.org/10.1016/j.gastrohep.2009.01.106

Kabarriti, R., Brodin, N. P., Ohri, N., Narang, R., Huang, R., Chuy, J.W., ..., Garg, M. K. (2019). Human papillomavirus, radiation dose and survival of patients with anal cancer. Acta Oncologica (Stockholm, Sweden), 58(I2), I745-I75I. https://doi.org//0.1080/0284186X.2019.1634834

Ki, E. Y., Lee, Y. K., Lee, A., \& Park, J. S. (2018). Comparison of the PANArray HPV genotyping CHIP test with the cobas $4800 \mathrm{HPV}$ and hybrid capture 2 tests for detection of HPV in ascus women. Yonsei Medical Journal, 59(5), 662-668.

Kobayashi, T., Sigel, K., Kalir, T., MacLeod, I. J., Liu, Y., \& Gaisa, M. (2019). Anal cancer precursor lesions in HIVinfected persons: Tissue human papillomavirus type distribution and impact on treatment response. Diseases of the Colon and Rectum, 62(5), 579-585. https://doi.org//0.1097/ DCR. 0000000000001307

Kok, T. C., Nooter, K., Tjong-A-Hung, S. P., Smits, H. L., Ter Schegget, J., Rotterdam, T. N., \& Rotterdam Oesophageal Tumour Study Group. (1997). No evidence of known types of human papillomavirus in squamous cell cancer of the oesophagus in a low-risk area. European Journal of Cancer, 33(II), I865-1868. https://doi.org/10.1016/S09598049(97)85984-9

Li, X., Gao, C., Yang, Y., Zhou, F., Li, M., Jin, Q., \& Gao, L. (2014). Systematic review with meta-analysis:The association between human papillomavirus infection and oesophageal cancer. Alimentary Pharmacology \& Therapeutics, 39(3), 27028I. https://doi.org/ I 0. I I I I/apt. 12574 
Li, S., Shen, H., Li, J., Hou, X., Zhang, K., \& Li, J. (2018). Prevalence of the integration status for human papillomavirus 16 in esophageal carcinoma samples. The Turkish Journal of Gastroenterology, 29(2), 157. https://doi.org//0.5152/ tjg.2018. 17568

Martinelli, M., Zappa, A., Bianchi, S., Frati, E., Colzani, D., Amendola, A., \& Tanzi, E. (20I2). Human papillomavirus (HPV) infection and genotype frequency in the oral mucosa of newborns in Milan, Italy. Clinical Microbiology and Infection, I8(6), El97-EI99. https://doi.org/I0.III I/j.1469069I.20I2.03839.x

Martínez-Ramírez, I., Carrillo-García,A., Contreras-Paredes,A., Ortiz-Sánchez, E., Cruz-Gregorio, A., \& Lizano, M. (2018). Regulation of cellular metabolism by high-risk human papillomaviruses. International Journal of Molecular Sciences, 19(7), 1839. https://doi.org//0.3390/ijms I 907/839

Mateos-Lindemann, M. L., Pérez-Castro, S., Rodríguez-Iglesias, M., \& Pérez-Gracia, M.T. (2017). Diagnóstico microbiológico de la infección por virus del papiloma humano. Enfermedades Infecciosas y Microbiología Clínica, 35(9), 593-602. https://doi.org/I0.1016/j.eimc.2016.05.008

Melkert, P.W. J.,Walboomers, J. M. M., Jiwa, N. M., Cuesta, M.A., Kenemans, P., \& Meijer, C.J.L.M.(1992).Multiple HPV I6-related squamous cell carcinomas of the vulva, vagina, anus, skin and cervix in a $3 \mathrm{I}$-year-old woman. European Journal of Obstetrics \& Gynecology and Reproductive Biology, 46(I), 53-56. https://doi.org// 0.1016/0028-2243(92)90280-C

Meyer, M. F., Huebbers, C. U., Siefer, O. G., Vent, J., Engbert, I., Eslick, G. D., ..., Preuss, S. F. (20 I4). Prevalence and risk factors for oral human papillomavirus infection in 129 women screened for cervical HPV infection. Oral Oncology, 50(I), 27-31. https://doi.org/ 0.1016/j.oraloncology.2013.10.009

Min, K. J., Kwon, S. H., Kim, K., Kim, S., Kim, H. J., Seong, S. J., ...,Lee, J. K. (2019). Clinical guideline for 9-valent HPV vaccine: Korean society of gynecologic oncology guideline. Journal of Gynecologic Oncology, 30(2), e3 I. https://doi. org/I0.3802/jgo.2019.30.e3 I

Moon, J. H., Jeong, K., Kim, K., Lee, C., Jin, M. S., \& Ryu, H. S. (2019). Comparison of clinical performance of two high-throughput liquid bead microarray assays, GeneFinder and CareGENE, for cervical screening in the general population. Archives of Virology, 164(II), 2699-2706. https://doi.org/10.1007/s00705-019-04379-7

Morgan, I. M., DiNardo, L. J., \& Windle, B. (2017). Integration of human papillomavirus genomes in head and neck cancer: Is it time to consider a paradigm shift? Viruses, 9(8), 208. https://doi.org// 0.3390/v9080208

Ono, K., Sugahara, K., Nomura, T., Takano, N., Shibahara, T., \& Katakura, A. (20I4). Multiple HPV subtypes infection in Japanese oral squamous cell carcinoma. Journal of Oral and Maxillofacial Surgery, Medicine, and Pathology, 26(2), 128132. https://doi.org//0.1016/j.ajoms.2013.01.00 I
Otter, S., Whitaker, S., Chatterjee, J., \& Stewart, A. (2019). The human papillomavirus as a common pathogen in oropharyngeal, anal and cervical cancers. Clinical Oncology, $3 I$ (2), 81-90. https://doi.org//0.1016/j.clon.2018.10.004

Pan, C., Issaeva, N., \& Yarbrough, W. G. (20I8). HPV-driven oropharyngeal cancer: Current knowledge of molecular biology and mechanisms of carcinogenesis. Cancers of the Head \& Neck, 3(I), 12. https://doi.org//0.1/86/s41199018-0039-3

Pérez, S. M., Quiñones, W. H., Oramas, B. G., Domínguez Álvarez, C., Lazo Del Vallín, S., \& Elvirez Gutierrez, A. (2003). Virus del papiloma humano. Actualización y presentación de un caso de carcinoma esofágico asociado a VPH. Revista Latinoamericana de Patología Clínica y Medicina de Laboratorio, 50(I), 12-19.

Quintero, K., Giraldo, G.A., Uribe, M. L., Baena, A., Lopez, C., Alvarez, E., \& Sanchez, G. I. (20I3). Human papillomavirus types in cases of squamous cell carcinoma of head and neck in Colombia. Brazilian Journal of Otorhinolaryngology, 79(3), 375-38I. https://doi.org//0.5935//8088694.20130065

Rintala, M., Grénman, S., Puranen, M., \& Syriänen, S. (2006). Natural history of oral papillomavirus infections in spouses: A prospective Finnish HPV family study. Journal of Clinical Virology, 35(I), 89-94. https://doi.org//0.1016/j. jcv.2005.05.012

Riviere, M., \& Bernhard, W. (1960). Examination by electron microscope of the VX2 tumour of the domestic rabbit derived from the Shope papilloma. Bulletin de l'Association Francaise pour L'etude du Cancer, 47, 570.

Robayo, D. A. G., Erira, H. A. T., Jaimes, F. O. G., Torres, A. M., \& Galindo, A. I. C. (2019). Oropharyngeal squamous cell carcinoma: Human papilloma virus coinfection with streptococcus anginosus. Brazilian Dental Journal, 30(6), 626-633. https://doi.org/I0.1590/0 I03-6440201902805

Rodríguez Trujillo, A. (20I8). Utilidad de la determinación VPH, genotipado y tinción dual p/6/Ki67 en la prevención secundaria del cáncer de cuello de útero (Tesis doctoral). Universidad de Barcelona.

Roesch-Dietlen, F., Cano-Contreras, A. D., Sánchez-Maza, Y. J., Espinosa-González, J. M.,Vázquez-Prieto, M. Á., Valdés-de la O, E., ...,Remes-Troche, J. M. (2018). Frecuencia de infección por virus del papiloma humano en pacientes con cáncer del aparato digestivo. Revista de Gastroenterología de México, 83(3), 253-258. https://doi.org//0.10 I6/j. rgmx.2017.09.003

Rüdlinger, R., \& Buchmann, P.( (989). HPV I6-positive bowenoid papulosis and squamous-cell carcinoma of the anus in an HIV-positive man. Diseases of the Colon \& Rectum, 32(I2), I042-I045. https://doi.org/I0.1007/BF02553878 
Isabel Cristina Almonacid Urrego, Carmen Cecilia Almonacid Urrego, Sonia Marcela Rosas Arango, Edith del Carmen Hernández Rojas, Johanna Lizeth González Devia, Revista Logos Ciencia \& Tecnología, I3(I): I 29-143

Salina Zhang, B. S., Batur, P., \& NCMP, C. (2019). Human papillomavirus in 2019:An update on cervical cancer prevention and screening guidelines. Cleveland Clinic Journal of Medicine, 86(3), I73. https://doi.org/10.3949/ccjm.86a.18018

Saxena, P. P., Fernandes, D. J., Vidyasagar, M. S., Singh, A., \& Sharan, K. (2016). Detection of human papilloma virus in patients with squamous cell carcinoma of the esophagus planned for definitive chemo-radiotherapy, and a study of their clinical characteristics. Journal of Cancer Research and Therapeutics, I2(2), 87I. https://doi.org/I0.4I03/0973|482. | 6897|

Schäfer, G., Kabanda, S., Van Rooyen, B., Marušič, M. B., Banks, L., \& Parker, M. I. (20I3). The role of inflammation in HPV infection of the Oesophagus. BMC Cancer, I3(I), I-II. https://doi.org/10.1 186/147|-2407-13-185

Serena-Gómez, E., Bologna-Molina, R. E., Nevarez-Rascon, A., \& Rocha Buelvas, A. (20II). Prevalencia del VPH en el proceso de malignización de lesiones de vías aerodigestivas superiores. International Journal of Odontostomatology, 5(I), 5-12. https://doi.org/10.4067/S07/8$381 \times 2011000100001$

Shope R. E. (1937). Immunization of rabbits to infectious papillomatosis. The Journal of Experimental Medicine, 65(2), 219 23I. https://doi.org//0.1084/jem.65.2.219

Siegel, R. L., Miller, K. D., \& Jemal, A. (2020). Cancer statistics, 2020. CA:A Cancer Journal for Clinicians, 70(I), 7-30. https:// doi.org/I0.3322/caac.21590

Silva, R., León, D., Brebi, P., lli, C., Roa, J. C., \& Sánchez, R. (20I3). Diagnóstico de la infección por virus papiloma humano en el hombre. Revista Chilena de Infectología, 30(2), 186-192. https://doi.org/10.4067/S07/6-10182013000200009

Stokłosa, P., Borgström, A., Kappel, S., \& Peinelt, C. (2020). TRP channels in digestive tract cancers. International Journal of Molecular Sciences, 2I(5), 1877. https://doi.org/10.3390/ ijms2 1051877

Syrjänen, K. J., \& Pyrhönen, S. ( 1982). Demonstration of human papilloma virus antigen in the condylomatous lesions of the uterine cervix by immunoperoxidase technique (with I color plate). Gynecologic and Obstetric Investigation, I4(2), 90-96. https://doi.org/10.1 159/000299456

Taberna, M., Mena, M., Pavón, M. A., Alemany, L., Gillison, M. L., \& Mesía, R. (2017). Human papillomavirus-related oropharyngeal cancer. Annals of Oncology, 28(10), 2386-2398. https://doi.org/10.1093/annonc/mdx304

Tampi, C., Pai, S., Doctor,V. M., Plumber, S., \& Jagannath, P.(2005). HPV-associated carcinoma of esophagus in the young. International Journal of Gastrointestinal Cancer, 35(2), I35142. https://doi.org// 0.1385/IJGC:35:2: 135
Tasneem, M., Hassan, M., Khan, A., Arabdin, M., \& Qamar, M. A. (2019). Frequency of human papilloma virus in patients with oesophageal squamous cell carcinoma in Khyber Pakhtunkhwa.JPMA.The Journal of the Pakistan Medical Association, 69(5), 738-740.

Termine, N., Giovannelli, L., Matranga, D., Caleca, M. P., Bellavia, C., Perino, A., \& Campisi, G. (20II). Oral human papillomavirus infection in women with cervical HPV infection: New data from an Italian cohort and a metanalysis of the literature. Oral Oncology, 47(4), 244-250. https://doi. org/10.1016/j.oraloncology.201 I.02.01 I

Tornesello, M. L., Monaco, R., Nappi, O., Buonaguro, L., \& Buonaguro, F. M. (2009). Detection of mucosal and cutaneous human papillomaviruses in oesophagitis, squamous cell carcinoma and adenocarcinoma of the oesophagus. Journal of Clinical Virology, 45(I), 28-33. https://doi. org/l0.1016/j.jcv.2009.02.004

Tóth, E. (2018). Pathology of HPV-associated oropharyngeal squamous cell carcinoma. Magyar Onkologia, 62(3), I 39-I 44

Tsikis, S., Hoefer, L., Charnot-Katsikas, A., \& Schneider, J. A. (2016). Human papillomavirus infection by anatomical site among Greek men and women:A systematic review. European Journal of Cancer Prevention:The Official Journal of the European Cancer Prevention Organisation (ECP), 25(6), 558. https://doi.org/I0.1097/CEJ.0000000000000207

Valari, O., Koliopoulos, G., Karakitsos, P., Valasoulis, G., Founta, C., Godevenos, D., ..., \& Paraskevaidis, E. (20I I). Human papillomavirus DNA and mRNA positivity of the anal canal in women with lower genital tract HPV lesions: Predictors and clinical implications. Gynecologic Oncology, I22(3), 505-508. https://doi.org/10.1016/j.ygyno.2011.05.033

Vieira, C. L., Lopes, J. C., \& Velosa, J. (20I3). A case of esophageal squamous cell carcinoma with positive HPV II. Gastroenterología y Hepatología, 36(5), 3 I I-3 I5. https://doi. org/10.1016/j.gastrohep.2012.09.003

Vonsky, M.,Shabaeva, M., Runov,A., Lebedeva, N., Chowdhury, S., Palefsky, J. M., \& Isaguliants, M. (2019). Carcinogenesis associated with human papillomavirus infection. Mechanisms and potential for immunotherapy. Biochemistry (Moscow), 84(7), 782-799. https://doi.org/10.1/34/ S0006297919070095

Wang, X., Tian, X., Liu, F., Zhao, Y., Sun, M., Chen, D., ..., Ke, Y. (2010). Detection of HPV DNA in esophageal cancer specimens from different regions and ethnic groups: A descriptive study. BMC Cancer, 10, 19. https://doi. org/10.1 186/1471-2407-10-19

Yahyapour, Y., Shamsi-Shahrabadi, M., Mahmoudi, M., Motevallian, A., Siadati, S., Shefaii, S.,..., Keyvani, H. (2013). High-risk and low-risk human papillomavirus in esophageal squamous cell carcinoma at Mazandaran, Northern Iran. Pathology Oncology Research: POR, 19(3), 385-39 I. https://doi.org/ I 0. I007/s I 2253-0 I 2-9590-0 
Zambrano-Ríos, D., Fernández, F., Matta-Miramar, A., Arbelaez, A., Herrera-Castañeda, E., \& Castillo, A. (2019). Detección del virus del papiloma humano en mucosa oral de mujeres de Cali, Colombia. Infectio, 23(3), 266-270.

Zeng, Z. M., Luo, F. F., Zou, L. X., He, R. Q., Pan, D. H., Chen, X., ...,Chen, G. (2016). Human papillomavirus as a potential risk factor for gastric cancer: A meta-analysis of 1,917 cases. OncoTargets and Therapy, 9, 7105-7I I4. https://doi. org/I0.2147/OTT.SII5053
Zhang, B., Chen, X., Zhou, Q., Song, Y., Sun, S., \& Cheng, H. (2018). Human gene expression microarray analysis of the HPV 6bE7-HaCaT stable cell line. Gene, 657, 60-68. https://doi.org/10.1016/j.gene.2018.02.067

Zur Hausen H. (1983). Similarities of papillomavirus infections with tumour promoters. Princess Takamatsu Symposia, I4, 147-152. 